\title{
Medical students in Indonesia: an invaluable living gemstone during coronavirus disease 2019 pandemic
}

Gilbert Lazarus ${ }^{1}$, Ghea Mangkuliguna ${ }^{2}$ and Ardi Findyartini ${ }^{3,4}$

${ }^{1}$ Faculty of Medicine, Universitas Indonesia, ${ }^{2}$ School of Medicine and Health Sciences, Atma Jaya Catholic University of Indonesia, ${ }^{3}$ Department of Medical Education, Faculty of Medicine, Universitas Indonesia, and ${ }^{4}$ Medical Education Center, Indonesia Medical Education and Research Institute, Faculty of Medicine, Universitas Indonesia, Jakarta, Indonesia

\section{Introduction}

Starting in late December 2019, coronavirus disease 2019 (COVID-19) has brought devastating impacts to global economy and health, infecting nearly seven million people across 215 countries and accounting for hundred thousands of deaths [1]. With the declaration of this disease as a pandemic, more aggressive measures against COVID-19 have been taken, including shutting down schools and other public places to reduce disease transmission [2]. Despite evident loss in learning opportunities, medical students in Indonesia have turned this shortcoming into an advantage by volunteering in numerous activities. This article aims to deliver authors perspectives and recommendations on the role of Indonesian medical students during COVID-19 pandemic.

\section{COVID-19 in Indonesia: are we on the right track?}

"Indonesia is still battling against COVID-19 pandemic, and further reinforcements are needed to ensure a winning battle."

The battle of COVID-19 in Indonesia began on 2 March 2020 when two patients tested positive for the virus. Since then, the situation has escalated rapidly, resulting in 32,033 positive cases, 1,883 deaths, and 10,904 recoveries as of 9 June 2020 [1]. In order to flatten the curve, strict countermeasures must be implemented immediately and effectively, which has been executed by implementing large scale social distancing to preserve health system capacity and prevent its collapse. During these times, the robustness of health system becomes fundamental in determining
Received: April 28, 2020 • Revised: June 9, 2020 • Accepted: June 25, 2020 Corresponding Author: Gilbert Lazarus (https://orcid.org/0000-0002-3605-6167) Faculty of Medicine, Universitas Indonesia, Jl. Salemba Raya No. 6, RW 5, Kenari, Kec. Senen, Kota Jakarta Pusat, Jakarta 10430, Indonesia

Tel: +62.82338989696 Fax: +62.213901814 email: gilbert.lazarus@ui.ac.id
Korean J Med Educ 2020 Sep; 32(3): 237-241.

https://doi.org/10.3946/kjme.2020.165

eISSN: $2005-7288$

(C) The Korean Society of Medical Education. All rights reserved. This is an open-access article distributed under the terms of the Creative Commons Attribution Non-Commercial License (http:// creativecommons.org/licenses/by-nc/3.0/), which permits unrestricted non-commercial use, distribution, and reproduction in any medium. provided the original work is properly cited. 
the course of COVID-19 in Indonesia. Although it is true that stakeholders have endeavored to support the health system, we believe that further reinforcements are essential to mitigate this outbreak, which may be done by expanding mass testing and mass production of necessary medical equipment as well as caring for healthcare workers.

\section{Indonesian medical students in COVID- 19 pandemic: roles and recom- mendations}

COVID-19 poses imminent threats to the health system. Without effective countermeasures to prevent its collapse, further loss may be inevitable, which calls for the need of a withstanding and effective health system. Indeed, an effective health system requires productive healthcare providers. However, on daily occasions, the workloads of healthcare providers are already strenuous, let alone a pandemic. Thus, lending a hand to them by doing simple tasks might alleviate their burdens and prevent further damages. In this regard, Indonesian medical students have taken initiatives to aid their future peers (i.e., health workers). Although they are still apprentices, we have to acknowledge that their sense of obligations and collegiality to their future peers are noteworthy.

First, Indonesian medical students have helped ensuring adequate supplies to health facilities by raising funds and donations. These initiatives were achieved by establishing volunteering organizations, utilizing promotional media, pitching for potential stakeholders, and delivering the essentials (i.e., personal protective equipment [PPE] and food supplies) to health facilities, all of which were done independently by medical students [3]. To this date, these budding initiatives have resulted in hundreds of thousands of food and PPE donations to over 100 hospitals throughout Indonesia, which surely have helped sustaining the health system by supporting and protecting frontline workers.

Second, medical students have taken part in risk communication and contact tracing. In this regard, medical students promote physical distancing and proper hygiene habits, busting local myths, as well as disseminating reliable health information extensively in hope to increase health literacy and dampen the chaos and panic caused by circulating rumors and news. These initiatives have been accomplished through several platforms, mainly through the use of news and social media. In addition to online media, several medical students have also developed a mobile application that enables its users to perform risk assessments and obtain health information related to COVID-19 [4]. Furthermore, Indonesian Medical Students' Executive Board has collaborated with Indonesian Ministry of Education of Culture and initiated a joint project to invite volunteers to aid the management of COVID-19 pandemic in Indonesia, where medical students may apply as health volunteers. Supervised by medical experts, these medical students may participate in the tracing and management of people who had contact with COVID-19 cases [5].

Even though medical students have participated in numerous volunteering activities, we believe that their potential could be further maximized. In United States, in addition to the aforementioned initiatives, medical students may take part in childcare assistance, in-direct patient outreach, researches, and test center in-take. Furthermore, clinical-year medical students may also help in providing clinical care to non-COVID-19 patients and even to COVID-19 patients, if necessary [6]. These opportunities may be adjusted to fit medical students in Indonesia but should encompass available prospects for both medical students in their pre-clinical 
and clinical year.

While the role of Indonesian medical students in non-clinical opportunities are already well-established, their involvements in clinical opportunities are still minimal. This is particularly aggravating for clinicalyear medical students as their refinement as future clinicians are hindered. Although it is true that their involvements in clinical care would consume more PPE, their years of experiences and knowledge in medicine field might be of help when caring for patients. Furthermore, the risks of deploying clinical-year medical students are lower than that of retired clinicians which are at higher risks of contracting complications [7], and that it will take much more efforts and resources to hire and train new workforces in such short order [8].

"Indonesian medical students have contributed invaluably to the country by volunteering in numerous relief aids. Yet, the minimum opportunities for Indonesian medical students, especially clinical-year students, to partake in clinical fields during these times may hinder their preparations as future doctors."

Given these circumstances, we therefore encourage medical schools and relevant stakeholders to assess the possibility of involving clinical-year medical students in the clinical care of patients during these times. These involvements may or may not be related to COVID-19 patients, as they may even help in providing clinical care to outpatient services to people with chronic conditions and in-patient services to those without COVID-19 [7]. Nevertheless, given the high risks of exposure and contraction, we believe that these policies should be voluntary rather than mandatory. In addition, should these policies be implemented, the volunteering students should be provided with critical knowledge and skills in COVID-19 comprehensive management, adequate PPE, and supports in order to ensure their safety and well-being [9].

As we have observed the willingness of Indonesian medical students to help their peers and country in the midst of crisis, as well as the vulnerability of Indonesia to future outbreaks, we believe that it is also important to provide them with proper knowledge and training on outbreak mitigation and health system. In this regard, we encourage medical schools to integrate relevant courses into medical education curriculum. Medical education can equip medical students from both preclinical and clinical years with necessary knowledge and skills regarding prevention, comprehensive management, and public health education regarding COVID-19. A medical school in Indonesia has initiated an open online course to enrich medical students in Indonesia with critical issues around COVID-19, involving them in disseminating health knowledge regarding COVID-19 to communities and exposing them with the reality of 'living evidence' in many aspects of the pandemic [9]. Such curriculum enrichment approach has also been initiated by several other medical schools (e.g., Harvard Medical School [10]). In addition, since current COVID-19 outbreak countermeasures rely mostly on prevention and non-pharmaceutical interventions, medical schools are also encouraged to strengthen curriculum on disease prevention in addition to curative management subjects. Hence, during future outbreaks, medical students may be readily deployed without further ado, thus diminishing loss and preventing health system collapse.

Lastly, it is well understood that medical education curriculum should also aim in developing professionalism among medical students. The current pandemic raises concerns on how to address a lot of uncertainties with medical students (e.g., current policy during pandemic of not sending students for the clinical 
rotations) and how the issues will influence their professional development [11]. Despite all challenges, we believe that the emphasis of professional development of future medical doctors in medical education should even be stronger. This involves development of empathy and compassion with patients and communities as well as the awareness towards local and global policies on COVID-19 pandemic. Students' movement as volunteers during this time can be seen as important experiences which need to be reflected upon hence the lessons will have positive impacts on their professional development and professional identity formation [12]. A study has also found that medical volunteerism in global health may improve leadership skills and interprofessional teamwork developments [13]. It is also recommended for current medical curriculum to provide rooms for such learning processes that discuss students' current roles during pandemic, ethical reasoning of most appropriate venues to volunteer considering patient and student safety and their competencies, and well-being issues [14]. This is in line with professionalism development which addresses reliability, adherence to ethical principles, effective interactions with patients and their family, effective interaction within the healthcare system, and a commitment to improving the competence of oneself, other and the healthcare system [15].

"The voluntary participation of Indonesian medical students should be provided with continuing supports from stakeholders and the government, particularly by ensuring health and safety measures, providing knowledge and proper training, as well as potentiating their volunteering opportunities. All in all, their contributions have delivered substantial impacts on the pandemic control, medical education, as well as the development of their professionalism."

\section{Conclusions}

In the end, the outcomes of outbreaks depend largely on the readiness of government and stakeholders in mitigating them. However, we should remember that medical students are invaluable assets that yield prodigious potentials to enforce health system capacity. Given that medical students yield years of knowledge and experiences in medical field, we recommend medical schools in Indonesia to integrate relevant courses on outbreak mitigation and disease prevention into the medical curriculum, and relevant stakeholders to open opportunities for clinical-year medical students to involve themselves in clinical care according to their competencies, provided that the students are voluntarily recruited and given adequate knowledge and skills, proper PPE and adequate supports. We hope that the contribution of medical students during these moments may bring substantial impacts both for the pandemic control and for medical students' professional development.

\section{ORCID:}

Gilbert Lazarus: https://orcid.org/0000-0002-3605-6167;

Ghea Mangkuliguna: https://orcid.org/0000-0002-3436-0624; Ardi Findyartini: https://orcid.org/0000-0002-9601-3994

Acknowledgements: The authors would like to express their gratitude to Yosilia Nursakina, Joseph Mikhael Husin, and Dewi Anggraeni Kusumoningrum from Faculty of Medicine, Universitas Indonesia for their invaluable insights to the article.

Funding: The study was supported by Medical Education Center, Indonesia Medical Education and Research Institute (IMERI), Faculty of Medicine Universitas Indonesia and funded by Universitas Indonesia (grant number: NKB-1525/UN2.RST/HKP.05.00/2020). 
Conflicts of interest: No potential conflict of interest relevant to this article was reported.

Author contributions: Conception of the work, data collection and interpretation, and writing the original draft: GL, GM; and critical revision of the article and final approval for publication: GL, AF.

\section{References}

1. Infeksi Emerging, Kementerian Kesehatan Republik Indonesia. Current situation of developing coronavirus disease (COVID-19) June 8, 2020. https://covid19. kemkes.go.id/situasi-infeksi-emerging/info-corona-virus/sit uasi-terkini-perkembangan-coronavirus-disease-covid-199-juni-2020. Published 2020. Accessed June 9, 2020.

2. European Centre for Disease Prevention and Control. Novel coronavirus disease 2019 (COVID-19) pandemic: increased transmission in the EU/EEA and the UK: sixth update, 12 March 2020. https://www.ecdc.europa.eu/sites/default/ files/documents/RRA-sixth-update-Outbreak-of-novel-cor onavirus-disease-2019-COVID-19.pdf. Published 2020. Accessed April 24, 2020.

3. Faculty of Medicine, Universitas Indonesia. Supporting the medical team's struggle against COVID-19, FKUI students take social action. https://fk.ui.ac.id/berita/dukung-perjuangantim-medis-hadapi-covid-19-mahasiswa-fkui-lakukan-aksisosial.html. Published 2020. Accessed April 18, 2020.

4. Faculty of Medicine, Universitas Indonesia. EndCorona. http://endcorona.fk.ui.ac.id/. Published 2020. Accessed April 20, 2020.

5. Kementerian Pendidikan dan Kebudayaan Republik Indonesia. Guidebook for volunteer medical students fighting the COVID-19 pandemic. Jakarta, Indonesia: Kementerian Pendidikan dan Kebudayaan Republik Indonesia; 2020.

6. Murphy B. 5 Ways medical students can assist during the
COVID-19 pandemic. https://www.ama-assn.org/deliveringcare/public-health/5-ways-medical-students-can-assist-dur ing-covid-19-pandemic. Published 2020. Accessed April 22, 2020.

7. Miller DG, Pierson L, Doernberg S. The role of medical students during the COVID-19 pandemic. Ann Intern Med. 2020 Apr 7 [Epub]. https://doi.org/10.7326/M20-1281.

8. Bauchner H, Sharfstein J. A bold response to the COVID-19 pandemic: medical students, national service, and public health. JAMA. 2020 Apr 8 [Epub]. https://doi.org/10.1001/ jama.2020.6166.

9. Tim Modul Tanggap Pandemi COVID-19; Medical Education Unit, Faculty of Medicine Universitas Indonesia. COVID-19 pandemic response module. http://ocw.ui.ac.id/ course/view.php?id=75. Published 2020. Accessed May 31, 2020.

10. Buckley MR A COVID-19 curriculum. https://hms. harvard.edu/news/covid-19-curriculum. Published 2020. Accessed May 31, 2020.

11. Mian A, Khan S. Medical education during pandemics: a UK perspective: version 2. BMC Med. 2020;18(1):100.

12. Hutchinson T, Smilovitch M. Experiential learning and reflection to support professionalism and professional identity formation. In: Cruess SR, Cruess RL, Steinert Y, eds. Teaching Medical Professionalism: Supporting the Development of Professional Identity. 2nd ed. Cambridge, UK: Cambridge University Press; 2016: 97-112.

13. Keelan E. So you want to be a medical volunteer. Ulster Med J. 2015;84(3):220-221.

14. Stetson GV, Kryzhanovskaya IV, Lomen-Hoerth C, Hauer KE. Professional identity formation in disorienting times. Med Educ. 2020 Apr 28 [Epub]. https://doi.org/10.1111/ medu. 14202.

15. Wilkinson TJ, Wade WB, Knock LD. A blueprint to assess professionalism: results of a systematic review. Acad Med. 2009;84(5):551-558. 